\title{
Ethnoveterinary plants and practices used for ecto-parasite control in semi-arid smallholder farming areas of Zimbabwe
}

\author{
Emmanuel Tendai Nyahangare ${ }^{1 *}$, Brighton Marimanzi Mvumi ${ }^{2 \dagger}$ and Tonderai Mutibvu ${ }^{1+}$
}

\begin{abstract}
Background: The inclusion of traditional plant-based ecto-parasite control methods in primary health care of livestock is increasingly becoming an important intervention for improving livestock productivity in resource-challenged smallholder farming areas. In this study, commonly used plants used for the control of cattle ticks and other pests were identified through a survey in four semi-arid districts of Zimbabwe.

Methods: A standard structured questionnaire with details of demographics, socioeconomic status of households, livestock parasites, control practices and list of ethnoveterinary plants used was used to interview 233 knowledgeable smallholder farmers in four districts. Focus group discussions with community members further provided insights on how the plants were being used and other issues surrounding ecto-parasite control and indigenous knowledge systems in the study areas.

Results: The older generation ( $>40$ years) of the respondents were knowledgeable about ethnoveterinary plants and practices. Overall, 51 plant species were reportedly effective against cattle ticks and other livestock parasites. The most frequently mentioned plants were in descending order, Cissus quadrangularis (30.1\%), Lippia javanica (19.6\%), Psydrax livida (14.9\%) and Aloe sp (14.9\%). Most of the plant materials were prepared by crushing and soaking in water and spraying the extract on animals. Despite the knowledge of these useful pesticidal plants, the preferred animal health care for cattle and other highly ranked livestock species is still the use of commercial acaricides. Cattle dipping services were reported sporadic by $48 \%$ of the respondents. Traditional knowledge and plants are considered only as an alternative in the absence of conventional synthetic products.
\end{abstract}

Conclusions: Livestock farming communities know of plant species used for livestock ecto-parasite control. The plant species are mostly used to complement commercial products. More work, is required to confirm the acaricidal properties claimed by the farmers in order to optimize and promote sustainable use of these plants.

Keywords: Acaricidal plants, Cattle ticks, Indigenous knowledge, Smallholder farmers

\section{Background}

Livestock play a crucial livelihood role for $70 \%$ of the world's resource-poor population whose majority are living in rural areas [1]. Their importance is even greater in drier agro-ecological zones where crop production is restricted by low and poorly distributed rainfall coupled with recurrent droughts. Mostly, these areas are only

\footnotetext{
* Correspondence: nyahangaree@gmail.com

${ }^{\dagger}$ Equal contributors

'Department of Animal Science, Faculty of Agriculture, University of

Zimbabwe, P O Box MP167, Mt Pleasant, Harare, Zimbabwe

Full list of author information is available at the end of the article
}

ideal for extensive livestock husbandry (especially cattle and small ruminants), wild animals and drought resistant crops. While these areas are suitable for livestock, animal performance still remains subdued due to numerous interacting factors key amongst them, diseases and poor health management across all species.

One of the major health concerns affecting livestock are ecto-parasites, particularly ticks and tick-borne diseases (TTBD). At least $80 \%$ of the world's cattle population are at risk from TTBD [2,3]. Ticks affect cattle directly by causing skin damage opening up wounds 
which make the animal susceptible to secondary infection, and cause toxicosis and paralysis in some instances [4]. Indirectly and more importantly, ticks act as vectors of fatal diseases, for example babesiosis and theileriosis [5]. Minjauw and Mcleod [6] and Perry et al. [7] ranked high the effects of TTBDs on the livelihoods of resource-constrained smallholder farmers in developing countries of sub-Saharan Africa (SSA), Asia and Latin America while [8] identified TTBD as one of the most important health and management challenges in Africa ahead of tsetse fly and trypanosomiasis.

The widely accepted and most used method of ectoparasite control has been the use of commercial chemical acaricides. In many developing countries, however, the commercial acaricides may be inconsistently available or not available at all [9]. Other challenges emanating from the use of these modern products include the development of widespread host resistance, ever-increasing cost of acaricides, environmental toxicity of chemicals, residuals in animal products and harm to non-target organisms [10]. This has compelled researchers to explore other methods that can be used as alternatives. In developing countries, there have not been significant deliberate investments of time and resources to development of tick control methods that are better suited for marginalised and resource-challenged smallholder farming communities. Most products on the market have been developed to cater for thriving commercial farmers with exotic livestock breeds which are the opposite of smallholder farmers [7]. Many of the smallholder farmers cannot easily access professional veterinary services and products and often face serious cash flow problems which make regular and sustainable purchase of commercial synthetic acaricides a big challenge. All these factors clearly indicate that there must be other ways of addressing TTBD problems other than what is currently available. Many options have been postulated including use of vaccines and integration of systems with various degrees of adoption and successes [11].

One approach is to explore and integrate the existing conventional methods of health management and ethnoveterinary practices, particularly the use of pesticidal plants. From time immemorial, people have used natural plants to control agricultural pests but the practice has been overtaken by use of synthetic pesticides and acaricides [12]. There is, however, renewed interest in pesticidal plants and traditional practices with literature suggesting that they have a great potential against agriculture pests especially for poor farmers [13]. Some of the plants with demonstrated acaricidal activity across the world include Azadirachta indica A. Juss. [14,15]; Tephrosia vogelii Hook. f. [16,17]; Stylosanthes scarbra Vogel, [18]; Solanum dasyphyllum Schumach \& Thonn, [19], Cleome gynandra L. [20]; Melinis minutiflora P.
Beauv. [21]. In Zimbabwe, Madzimure et al. [22,23] confirmed acaricidal properties in Lippia javanica leaves (Burm.f.) Spreng. Solanum incanum L. fruits and Strychnos spinosa Lam. fruits which were targeted based on an earlier ethnobotanical knowledge survey [24]. The crude water extracts of the plants reduced tick populations on cattle even though the cattle were still classified as tick-infested according to Zimbabwe veterinary standards [25].

Scientific research and documentation of medicinal and pesticidal plants is still lagging behind in most developing countries, Zimbabwe included [12]. In Zimbabwe, no surveys that cover wider parts of the country have been conducted to collect information on plants that are useful in controlling livestock parasites to broaden the knowledge and resource-base. There are potentially effective plants in different parts of the country which need to be identified. Therefore, this study was commissioned to help build a database of acaricidal plants in Zimbabwe particularly from remote semi-arid areas. This knowledge will help in further research and development of alternative pest and parasite control options for smallholders farmers in Zimbabwe and other developing countries in similar circumstances.

\section{Materials and methods}

\section{Study sites}

Surveys to document ethnoveterinary practices used to control ticks and other parasites in livestock were conducted in four semi-arid districts of Zimbabwe covering natural agro-ecological regions IV and V. The basis for selection of these two regions was that livestock production is key to livelihoods of farmers in these zones because of the sporadic and unreliable rainfall which make crop production and other water-dependent enterprises a huge challenge. Any intervention that helps improve livestock productivity will most likely directly improve livelihoods of these communities. In ecological region IV, Matobo and Kadoma districts were purposively selected while Chiredzi and Muzarabani districts were also purposively selected from natural ecological region $\mathrm{V}$ (Figure 1). In each district, four culturally-rich wards, where ethnoveterinary practices are prevalent, were targeted for administration of the questionnaire. District agricultural and veterinary extension officials assisted in identifying suitable areas to conduct the surveys. This approach was used to increase the likelihood of getting useful information since traditional practices are areaspecific. With regard to human development, Matopo and Kadoma districts were ranked 36th and 43rd poorest districts in Zimbabwe, respectively; while Chiredzi and Muzarabani districts are ranked 52nd and 61st out of a total of 77 districts [26]. A short description of the study sites is presented in Table 1. 


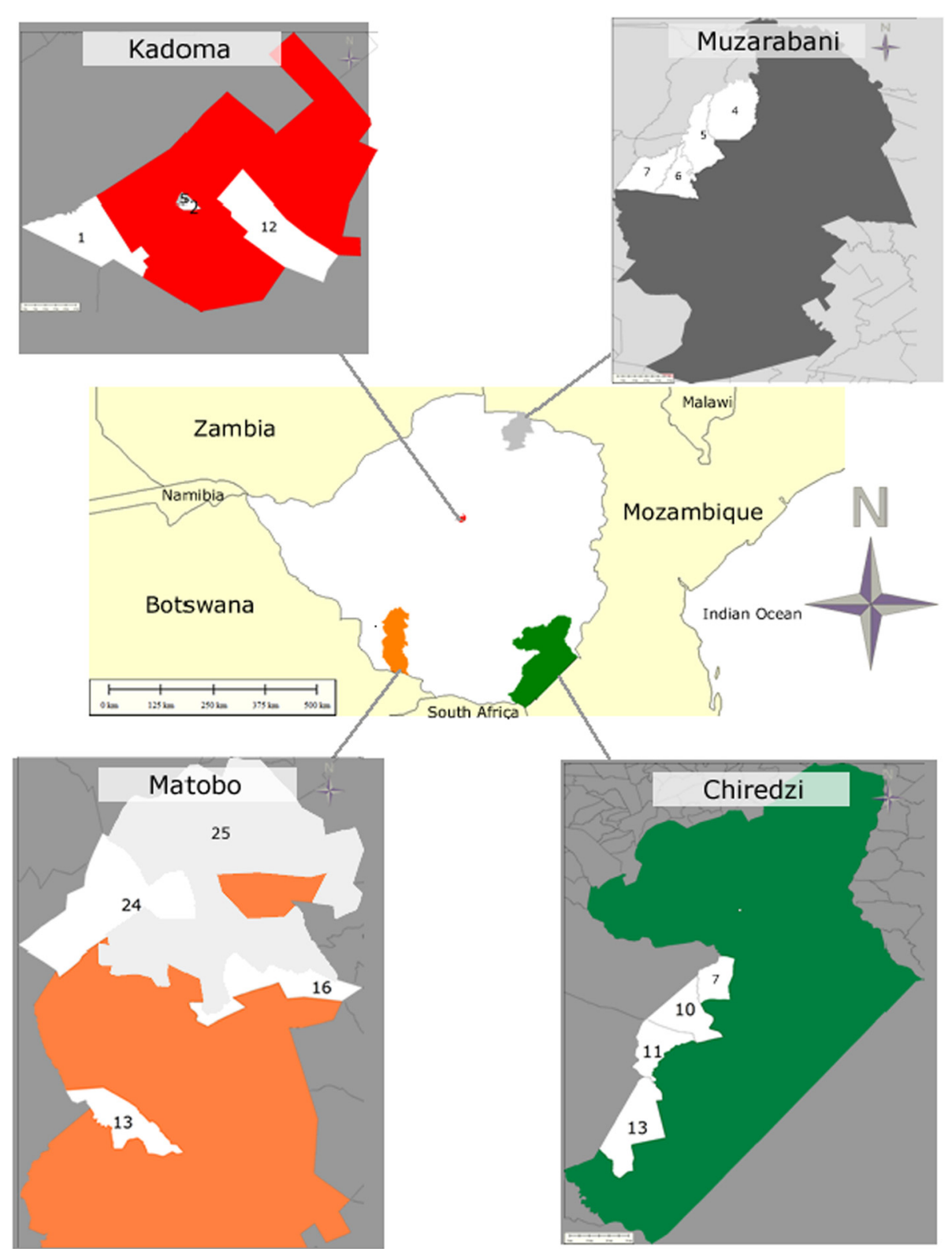

Figure 1 Map of Zimbabwe showing the study sites. The numbers withing the map denote administrative areas within the districts, locally known as Wards.

\section{Ethnobotanical data collection}

A total of 233 households (60 from Muzarabani, Sanyati and Matopo districts and 53 from Chiredzi district) were purposively selected depending on whether they kept livestock or not and if they had knowledge about ethnoveterinary practices. They were interviewed using a pretested standard structured questionnaire. The purposive sampling technique was chosen in order to increase the likelihood of obtaining detailed and useful information from respondents. The survey was conducted between January and April 2013 and sought information on ethno tick and other livestock pest control practices and issues surrounding their use. Local agricultural and veterinary extension staff assisted in the identification, selection of respondents and subsequent administration of the questionnaires. We confirm that in Zimbabwe research surveys of the nature reported in this study did not require ethical approval by committee since they did not involve the use of the plant materials surveyed on humans or animals. All interviewees were volunteers and consented to be interviewed and approved of the subsequent publication of survey responses. Apart from the questionnaires, further information on pesticidal plants was collected through focus group discussions (FGDs) with knowledgeable persons from 
Table 1 Some characteristics and description of the survey study sites

\begin{tabular}{|c|c|c|c|c|}
\hline District & Ward & Province & $\begin{array}{l}\text { Agro- } \\
\text { ecological } \\
\text { region }\end{array}$ & Characteristics of farming region \\
\hline \multirow[t]{4}{*}{ Kadoma } & 1 & \multirow{4}{*}{$\begin{array}{l}\text { Mashonaland } \\
\text { West }\end{array}$} & \multirow[t]{4}{*}{ III - IV } & \multirow{4}{*}{$\begin{array}{l}\text { Found on approximately } 18^{\circ} 19^{\prime} \text { S longitude and latitude } 29^{\circ} 53^{\prime} \mathrm{E} \text {, moderate to low average } \\
\text { rainfall } 450-600 \mathrm{~mm} \text {, semi-extensive farming of livestock and drought resistant fodder crops } \\
\text { [27] }\end{array}$} \\
\hline & 2 & & & \\
\hline & 5 & & & \\
\hline & 12 & & & \\
\hline \multirow[t]{4}{*}{ Matobo } & 13 & \multirow{4}{*}{$\begin{array}{l}\text { Matabeleland } \\
\text { South }\end{array}$} & \multirow[t]{4}{*}{ IV } & \multirow{4}{*}{$\begin{array}{l}\text { District is found at } 20^{\circ} 23^{\prime} \text { È latitude and } 28^{\circ} 30^{\prime} \text { S longitude. Average rainfall is } 450-650 \mathrm{~mm} \text {, area } \\
\text { is good for semi-extensive livestock and game ranching, common crops include drought } \\
\text { resistant maize, sorghum and millet [28] }\end{array}$} \\
\hline & 16 & & & \\
\hline & 24 & & & \\
\hline & 25 & & & \\
\hline \multirow[t]{4}{*}{ Chiredzi } & 7 & \multirow[t]{4}{*}{ Masvingo } & \multirow[t]{4}{*}{ V } & \multirow{4}{*}{$\begin{array}{l}\text { Area is found at about } 31^{\circ} 30^{\prime} \text { S longitude, } 21^{\circ} 10^{\prime} \mathrm{E} \text { latitude. It is one of the largest districts in } \\
\text { Zimbabwe with an average uncertain annual rainfall }<450 \mathrm{~mm} \text {; suitable for extensive cattle } \\
\text { production and game ranching [28] }\end{array}$} \\
\hline & 10 & & & \\
\hline & 11 & & & \\
\hline & 13 & & & \\
\hline \multirow[t]{4}{*}{ Muzarabani } & 4 & \multirow{4}{*}{$\begin{array}{l}\text { Mashonaland } \\
\text { Central }\end{array}$} & \multirow[t]{4}{*}{ V } & \multirow{4}{*}{$\begin{array}{l}\text { District is located at a longitude of } 16^{\circ} \mathrm{E} \text { and latitude of } 31^{\circ} \mathrm{S} \text { along the Mozambique - } \\
\text { Zimbabwe border. Average annual rainfall }<450 \mathrm{~mm} \text {. The area is suitable for subsistence } \\
\text { smallholder farming, cattle production and game ranching [28] }\end{array}$} \\
\hline & 5 & & & \\
\hline & 6 & & & \\
\hline & 7 & & & \\
\hline
\end{tabular}

the respective communities. Information regarding the vernacular names, part(s) used, methods of preparation, mode of application was documented during the interviews. Each plant was correctly identified by a qualified botanist and voucher specimens deposited at the National Herbarium and Botanical Garden in Harare, Zimbabwe.

\section{Data analyses}

Data collected were analyzed using SPSS version 21 (IBM Statistics, 2012). Frequencies, means and tables were generated for variables such as livestock species kept, major parasites affecting the livestock and the methods used for controlling them. Identified plants were ranked according to frequency of mention in all the districts. Qualitative data from FDGs were synthesised and summarised according to thematic areas.

\section{Results}

\section{Household demographics}

A total of 233 household heads responded to the questionnaire in the four districts of which $78.5 \%$ were males and $21.5 \%$ were females. Their average age was about 51 years and the household size averaged 7 people (Table 2). The age distribution of respondents showed that they were mostly of the older generation with the bulk of them over 40 years of age (Figure 2). About $6 \%$ were found in the youngest age group $(21-30)$ and only $2 \%$ were in the oldest group $(81-90)$.

\section{Livestock species kept by the farmers}

Most households owned different types of livestock which consisted mainly of poultry, cattle, goats, sheep, donkeys and pigs. Indigenous chickens were the most populous species kept per household with a mean estimate of 17 chickens (Figure 3). The highest population of cattle was found in Matopo district while goats were most populous in Chiredzi. There were more indigenous chickens kept in Kadoma than any other district. Across the districts, the mean number of sheep was very low. A detailed picture of the distribution of the livestock species by district is as shown in Figure 4.

\section{Ranking of animal species}

Despite chickens being the most populous species kept by respondents, cattle were ranked highest of all the species in terms of importance followed by indigenous chickens and then goats (Table 3). Other species kept by respondents in the survey areas and ranked lower include commercial chicken breeds, pigs, donkeys and various other less popular poultry species like guinea fowl and ducks.

Table 2 Summary of household demographics $(\mathbf{N}=233)$

\begin{tabular}{lll}
\hline Household details & Mean & Std. Deviation \\
\hline Age of household head (years) & 51.3 & 15.23 \\
Household size & 7.2 & 4.46 \\
Number of adult males (>18 years) & 2.0 & 1.52 \\
Number of adult females (>18 years) & 2.0 & 1.57 \\
Number of children (0-18 years) & 3.4 & 2.62 \\
\hline
\end{tabular}




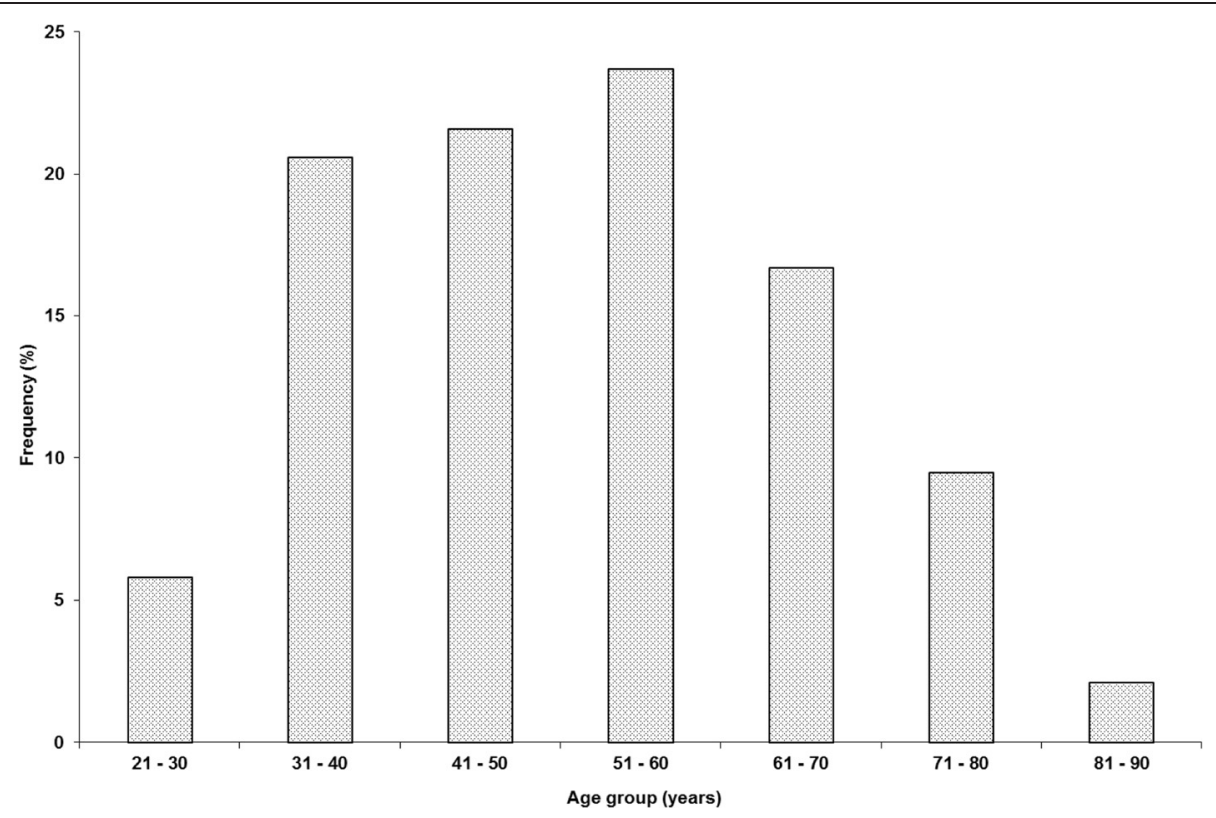

Figure 2 Age group distribution of respondents across the surveyed districts $(N=233$ ).

\section{Prevalent livestock parasites and their management}

Ticks were the most commonly identified parasites affecting mostly cattle, goats, donkeys and sheep (Table 4). Other parasites also reported include common flies and tsetse flies. Mites, fleas and lice were the most prevalent parasites in poultry species with the most common parasites for indigenous chickens being fleas and lice at $27.5 \%$ and $22.7 \%$ respectively (Table 4 ). Generally, parasites were controlled mostly by synthetic acaricides only for the highly ranked animal species (cattle, indigenous

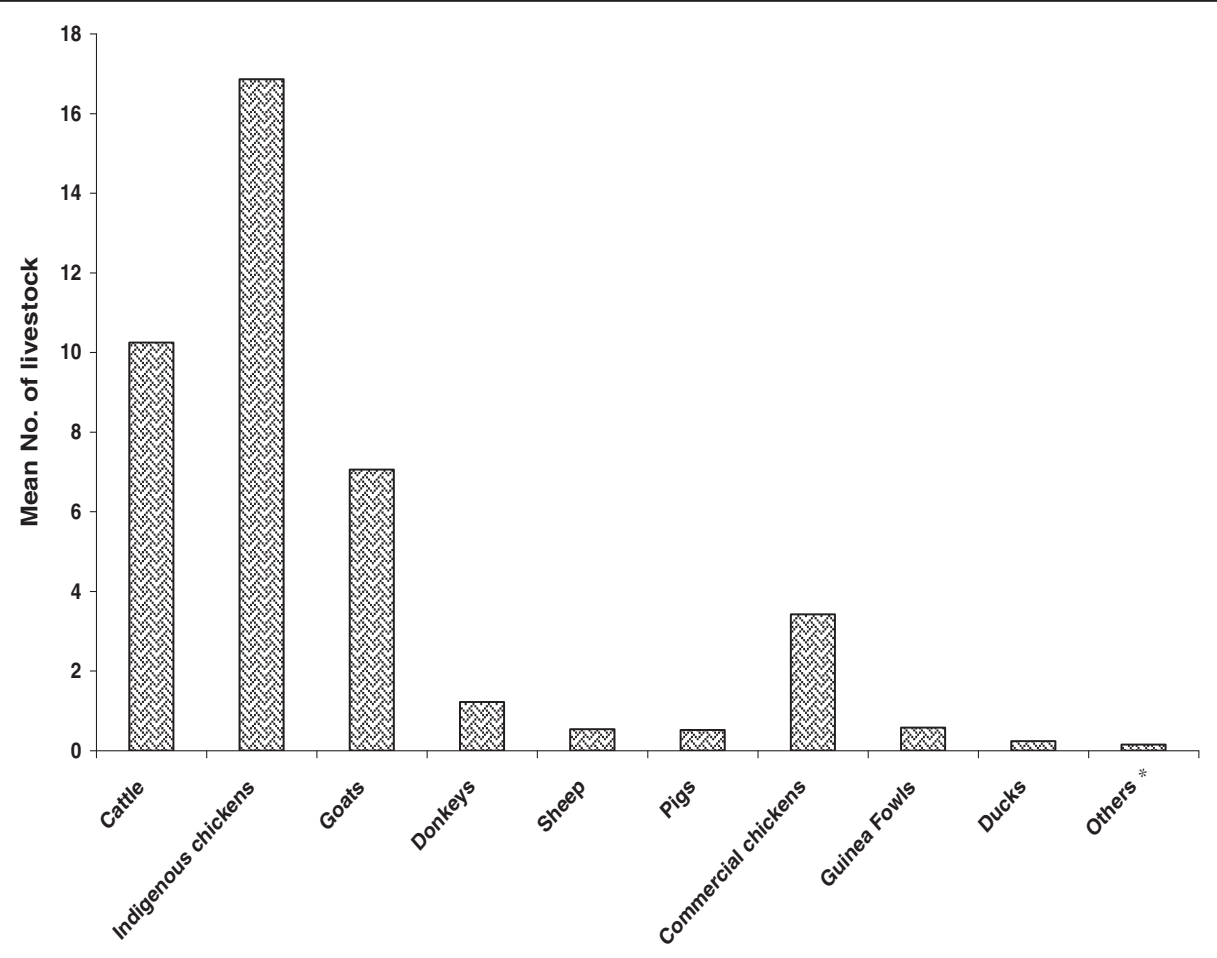

Livestock species

Figure 3 Average livestock numbers kept per household across the survey districts $(\boldsymbol{N}=\mathbf{2 3 3}) .{ }^{*}$ Others represents small livestock species like pigeons, rabbits and rock rabbits kept in small numbers. 


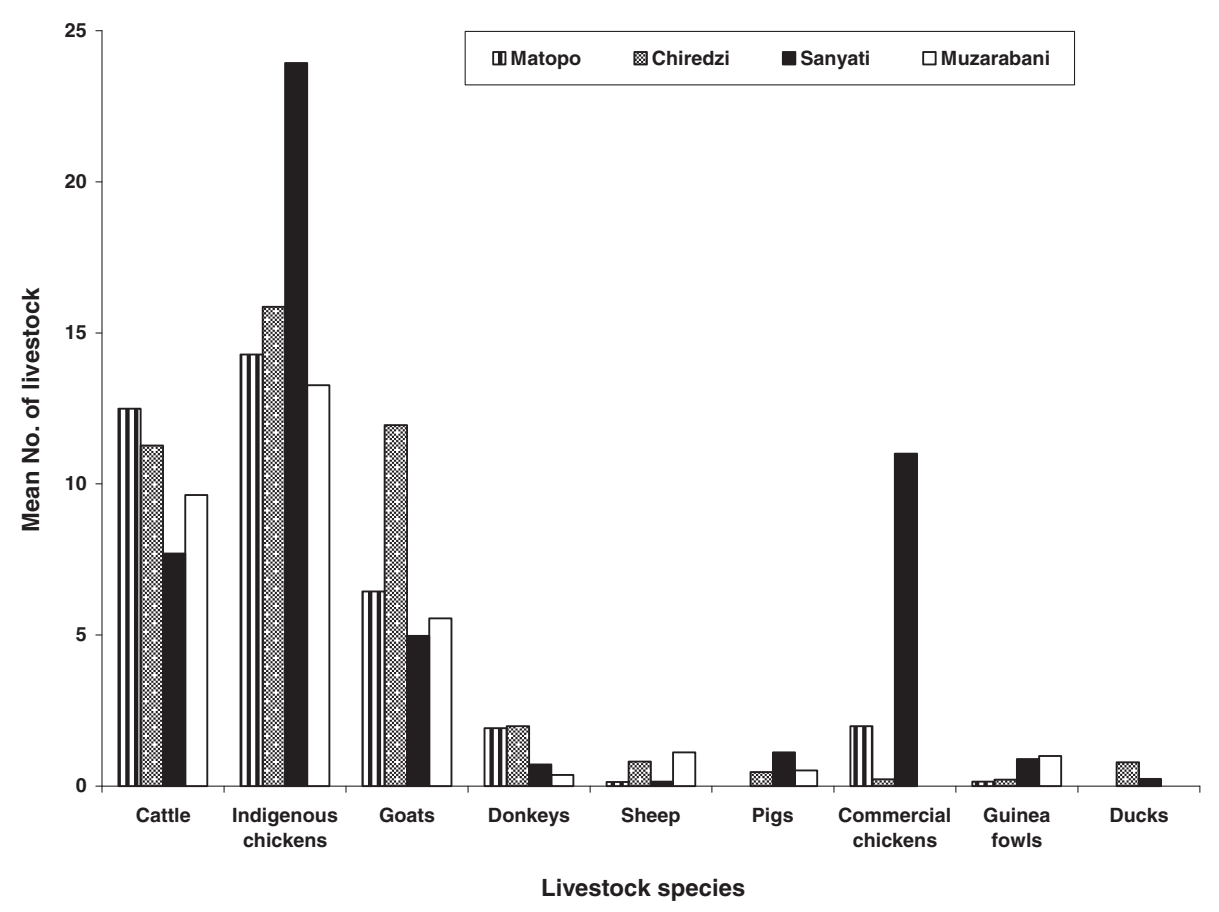

Figure 4 Mean number of livestock species by district $(\mathrm{N}=233)$.

chickens and goats) with the lowly ranked animals receiving little or no remedial action at all (Figure 5). The use of traditional practices alone was prevalent mainly in poultry production compared to other systems. A mixture of traditional practices and commercial products was prevalent mostly in cattle, indigenous chickens and goats. It was, however, minimal in pigs, sheep and donkeys (Figure 5).

\section{Status of cattle dipping in the survey areas}

A significant percentage of the respondents highlighted that dipping services were sporadic $(48 \%)$ and in some areas not available at all (12\%). However, $40 \%$ of the respondents had no challenges with availability of dipping

Table 3 Ranking of livestock species according to importance by respondents ( $N=233)$

\begin{tabular}{lll}
\hline Species & Rank & Frequency (\%) \\
\hline Cattle & 1 & 77.7 \\
Indigenous chickens & 2 & 76.9 \\
Goats & 3 & 56.6 \\
Donkeys & 4 & 28.4 \\
Sheep & 5 & 13.8 \\
Pigs & 6 & 10.7 \\
*Other species & 7 & 7.2 \\
Commercial chickens & 8 & 5.7 \\
\hline
\end{tabular}

*Refers to livestock species that were available in very small numbers which include; turkeys, ducks, rabbits, pigeons and guinea fowls. services. Chief amongst the reasons cited for inconsistent dipping services was the lack of veterinary services through Government support and high cost of acaricides (Figure 6). Other reasons included long distances to dip tanks, political instability, dysfunctional dipping infrastructure and unavailability of water.

\section{Use of pesticidal plants}

Many respondents (72.1\%) had some knowledge of plants used in the control of animal parasites whereas $27.9 \%$ were totally unaware. The knowledge was passed on orally mainly from the older generation of parents and grandparents (75.3\%). Other knowledge sources of pesticidal plants were local agricultural extension staff, relatives, Non-Governmental Organisations (NGOs), friends and the media in descending order (Figure 7).

Overall, a total of 51 different plant species effective against livestock parasites were identified from the survey. The most popular plants by frequency of mention were Cissus quadrangularis L. (30.1\%), Lippia javanica (19.6\%), Psydrax livida Willd. (14.9\%) and Aloe sp (14.9\%) (Figure 8). Cissus quadrangularis was particularly singled out as a very effective plant acaricide in Muzarabani, Kadoma and Chiredzi districts in FGDs with the farmers. Many other plant materials were not as well-known and were less mentioned by the respondents (Figure 8). The information on the specific pesticidal plants (trees, shrubs and grasses), preparation methods, parts of the plant used, targeted parasites, availability and other issues based on 
Table 4 The most frequently mentioned livestock parasites by species in the four districts

\begin{tabular}{|c|c|c|c|c|c|c|}
\hline \multirow[t]{2}{*}{ Livestock Species } & \multicolumn{6}{|c|}{ Common parasites as identified by respondents (\%) } \\
\hline & Ticks & Flies & Tsetse flies & Mange mites & Fleas & Lice \\
\hline Cattle & 81.0 & 0.9 & 0.4 & 0.4 & - & - \\
\hline Sheep & 5.6 & 0.4 & - & - & - & - \\
\hline Goats & 49.8 & - & 0.4 & 3.9 & 0.4 & 0.4 \\
\hline Indigenous chickens & - & 1.3 & - & 3.4 & 27.5 & 22.7 \\
\hline Commercial chickens & - & - & - & - & 0.4 & 0.9 \\
\hline Pigs & - & - & - & 2.2 & - & 1.3 \\
\hline Donkeys & 13.3 & 0.4 & - & - & 0.4 & 0.4 \\
\hline${ }^{*}$ Other species & - & 0.9 & - & - & 0.9 & 2.1 \\
\hline
\end{tabular}

*Refers to livestock species that were available in very small numbers. These include; turkeys, rabbits and guinea fowls. "-" means the ectoparasites were reported absent for that livestock species.

farmers' experiences are summarised in Table 5. The most common method of preparation of the plant materials was crushing the leaves/stems, soaking in water for variable periods and then spraying the animals. Other methods included dusting ashes of certain trees, shrubs and herbs over the animals and birds. In poultry, twigs and leaves of $L$. javanica were laid as bedding in the fowl run.

\section{Focus group discussions}

During discussions, farmers acknowledged that they were more knowledgeable about livestock medicinal plants than pesticidal plants in general. The practice of using ashes of different plants as acaricides, for example C. mopane tree, was based on the observation that donkeys regularly roll or bath in ashes in the villages and consequently, are rarely tick-infested despite not being dipped at all. Farmers in Muzarabani district showed awareness of aspects to do with intellectual property rights from previous exposure to studies on medicinal plants by other researchers. They felt that the scientists took advantage of them by extracting information from them and making money out of it with no acknowledgement of their input in monetary terms or otherwise. They demanded assurance that whatever came out from the deliberations would remain community property and that they should benefit as well. Separately, there was concern by farmers in all the districts about political interference and general lack of government support to arrest deteriorating health care provision to animals. In newly resettled areas, farmers lamented the long distances they must travel to access communal dip tanks.

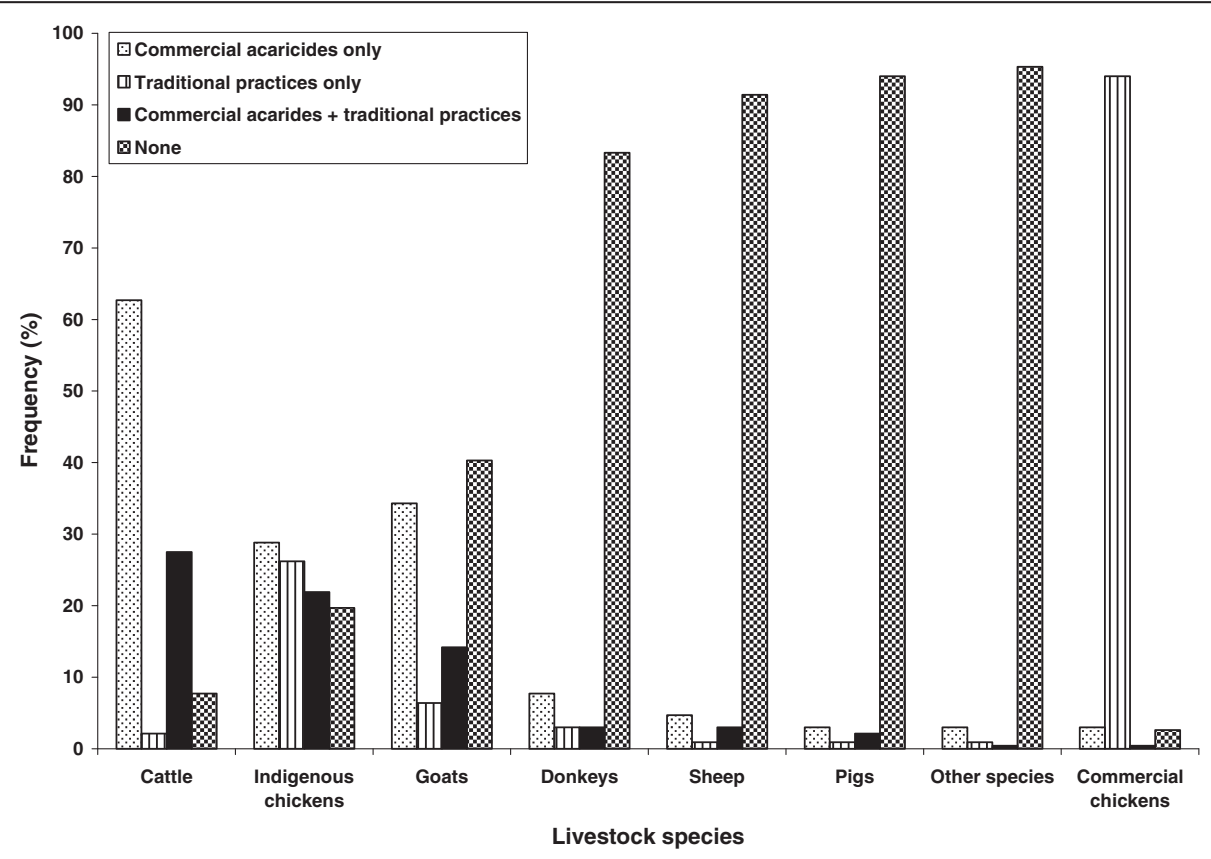

Figure 5 Livestock ecto-parasites management techniques by livestock species in the surveyed districts $(\mathrm{N}=233)$. 


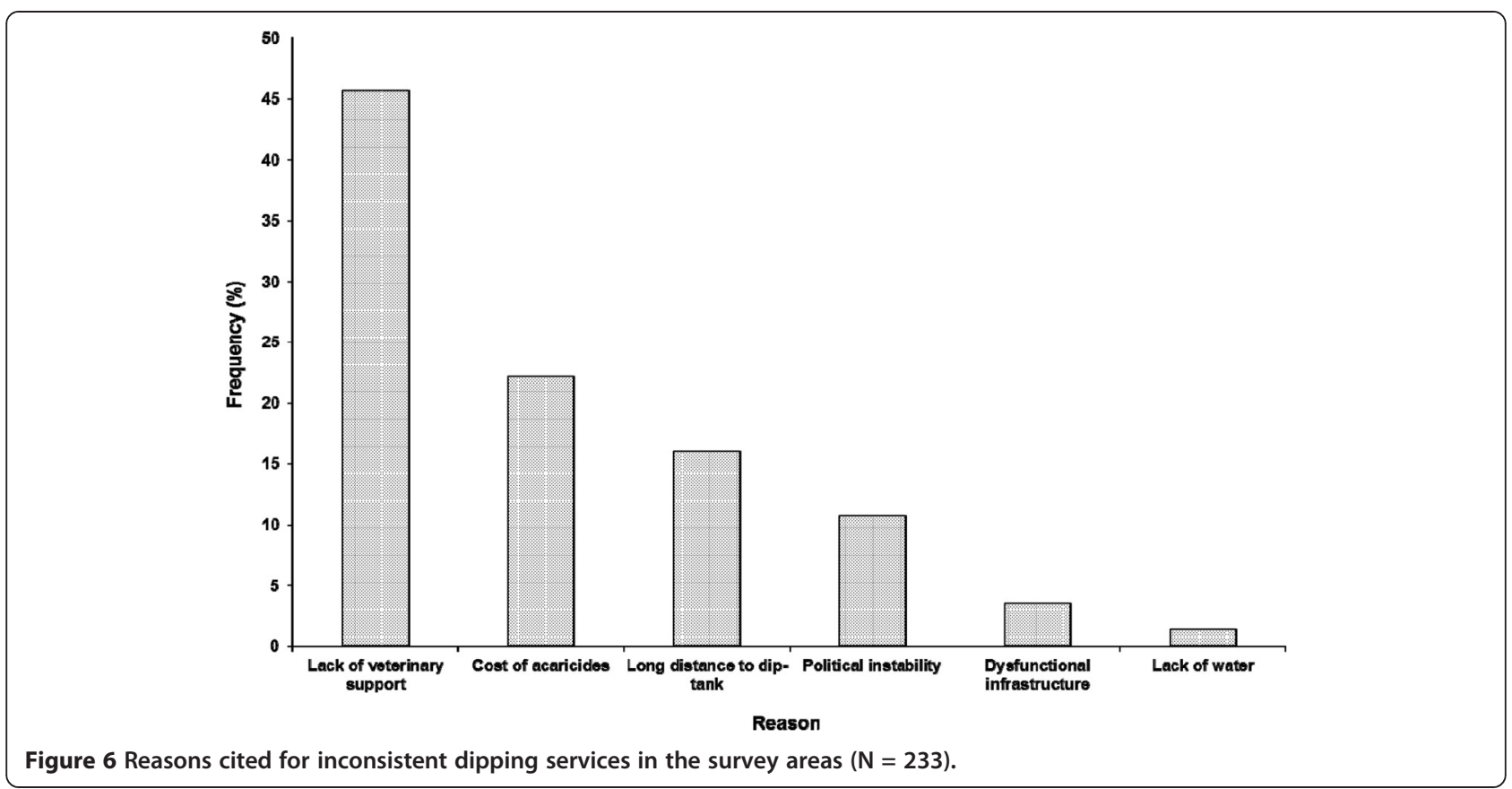

\section{Discussion}

\section{Household demographics}

The study showed that most of the respondents were of an older age ranging between 41-70 years of age. Similarly high, was the mean age (51.3 years) of the household head. This is due to the purposive nature of the sampling where the focus was on livestock farmers and younger generations were unlikely to own livestock as they were in the process of pursuing an educational career or other developmental avenues of life. The older generation were also more knowledgeable about the use of traditional plants in the provision of primary health care of animals. It is known that traditional knowledge and practices are normally found in the older generations as the younger generations generally disregard traditional practices as a result of direct and indirect effects of modernisation and globalisation [29-31].

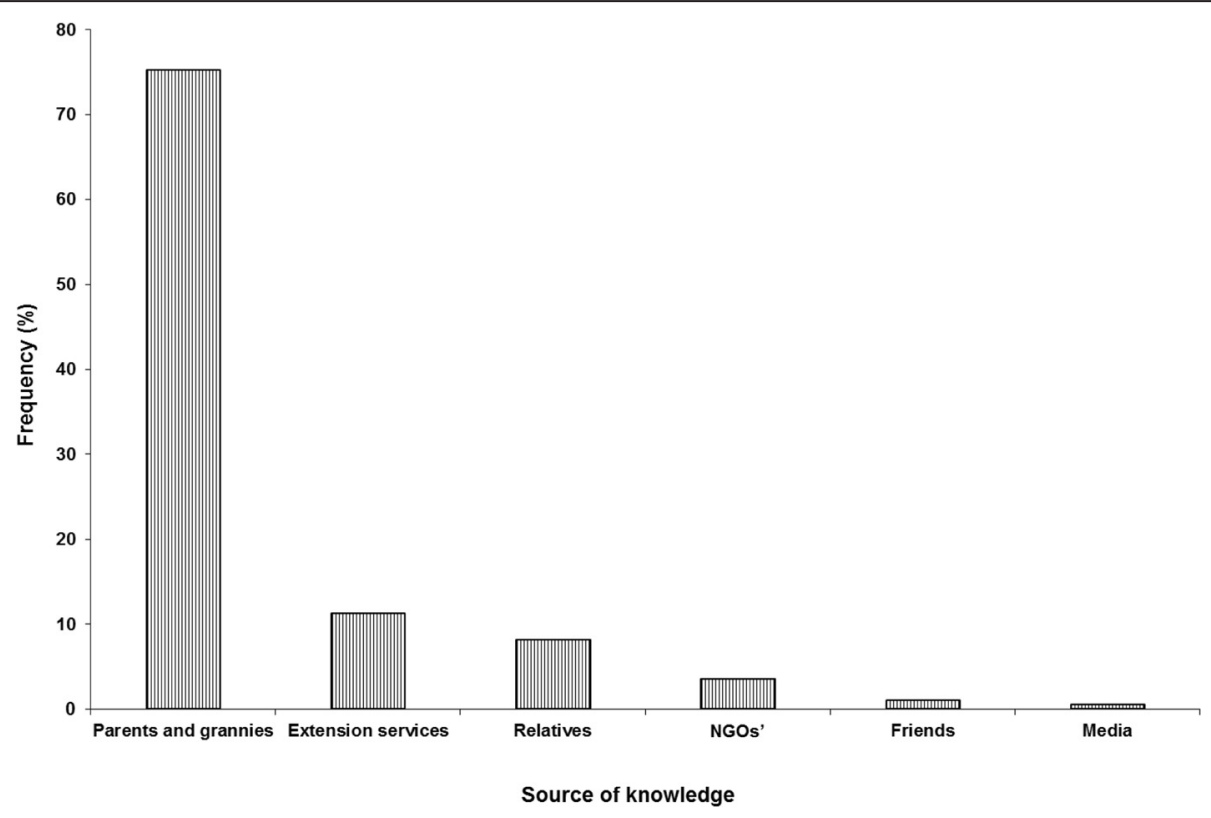

Figure 7 Sources of knowledge of acaricidal plants in the survey areas. 


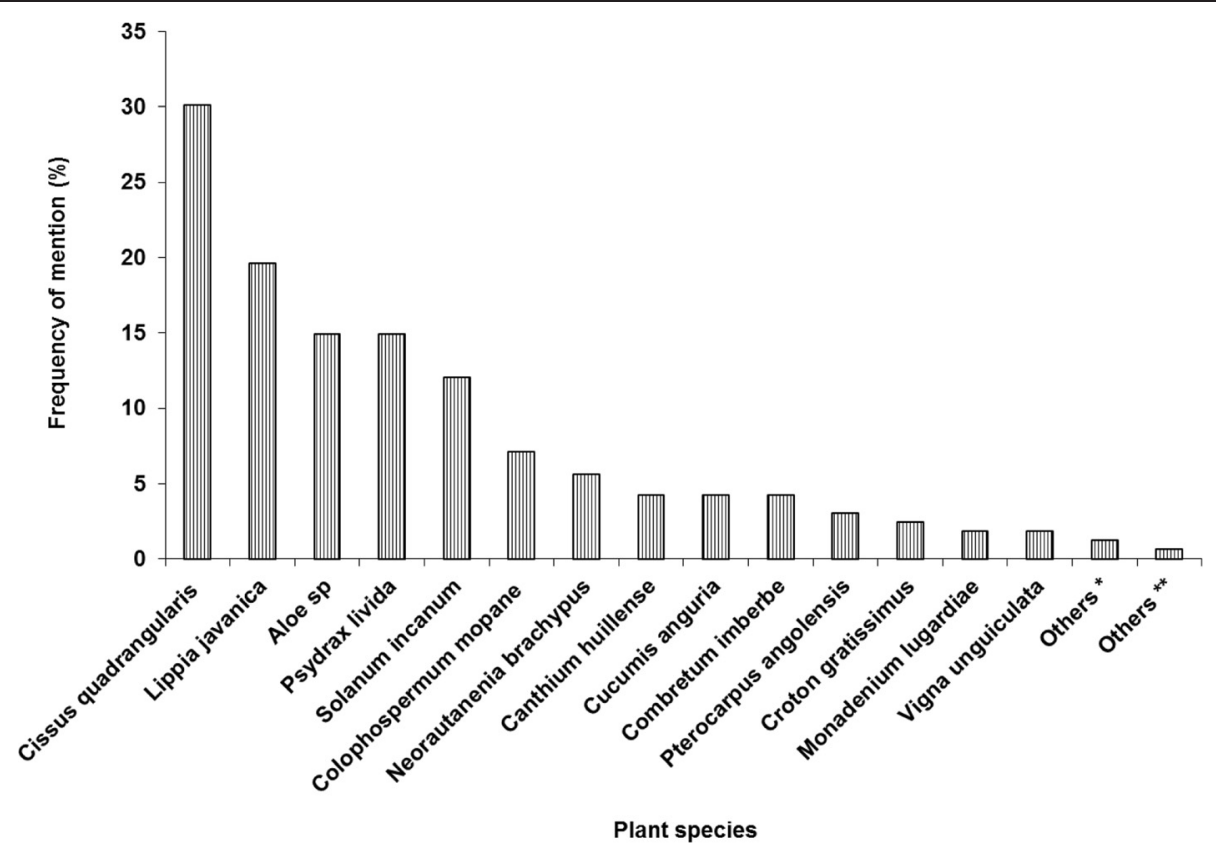

Figure 8 The most common acaricidal plants by frequency of mention $(\mathbf{N}=\mathbf{2 3 3}) .{ }^{*}$ Plant species with a frequency of 2 : Acacia karoo, Bauhinia petersian, Capsicum annuum, Clerodendrum eriophyllum, Vernonia colorata, Spirostachys africana, Strychnos spinosa, Terminalia sericea, Strychnos cocculoides, Zantedeschia albomaculata. ** Plant species with a frequency of 1: Albizia harveyi, Carissa edulis, Ornithogalum sp, Chimwamaruka, Euphorbia griseola, Gnidia kraussina, Kleinia sp, Jatropha curcas, Maerua edulis, Euclea divinorum, Mundorani, Rotheca eriphylla, Nicotiana tobaccum, Olinia ventosa, Sansevieria hyacinthoides, Senna singuena, Tagetes minuta, Xeroderris stuhlmannii, Zanthoxylum chalybeum.

\section{Livestock production in the survey areas}

Overall, indigenous chickens were the most populous livestock species averaging 16.9 birds per household which compares well with the national average in rural areas of Zimbabwe of around 17 birds [32]. Mutibvu and co-workers [33] also found an average of 16.1 birds per household in a survey carried out in Simbe Communal area of Gokwe South district of Zimbabwe. Indigenous chickens generally require minimal initial capital injection compared to other species and can also perform relatively well even under poor management. Almost every farmer can afford to raise the birds on the farm regardless of social status. Chickens provide the household with readily available cheap protein and can also be used as a form of quick off-take, thus playing a critical role in the livelihoods of farmers [34]. Kadoma district had the highest mean average of chickens kept per household. This can be explained by the fact that indigenous chickens also rely, to a lesser extent, on maize, sunflower and other grains. In Kadoma district, crop production is most favourable compared to the other districts.

Despite chickens being the most populous species, cattle were ranked as the most important livestock species on the farms. Cattle are considered very important because of the many socio-cultural and economic roles they play in the African society. They have multiple uses for smallholder farmers providing draught power; used in traditional rituals, providing milk, meat, manure and acting as social security among other important cultural roles [35-38]. The importance of cattle is also underscored by other researchers and $[39,40]$ who made similar observations. The other livestock species were ranked lower and had lower mean herd and flock sizes. Muchadeyi [32] reported that even though farmers keep other species such as commercial chicken breeds, pigs, donkeys and various other less popular poultry species like guinea fowl and ducks, they are generally ranked lower and their populations are also very low. Despite being lowly ranked, these species play important roles in the livelihoods of rural farmers. Donkeys for example were ranked fourth but are critical in the drier areas of the country where they provide a steady supply of draught power [41]. They are wellknown to be drought tolerant and easier to manage than cattle. The study areas experience frequent droughts hence donkeys occupy a very important niche. The only disadvantage of donkeys is that while other domesticated animal species can be used for milk and/or meat, not many people are known to prefer donkey products in Zimbabwe.

\section{Livestock parasites and control methods}

Common livestock parasites and pests identified in the survey Most farmers identified ticks as the most problematic pest in cattle and other animals. Other authors $[42,43]$ 
Table 5 Summary of plants used for ticks and other ecto parasites control, how they are used and status of availability

\begin{tabular}{|c|c|c|c|c|c|c|c|}
\hline $\begin{array}{l}\text { Scientific name \& } \\
\text { Voucher number }\end{array}$ & Family name & $\begin{array}{l}\text { Local names } \\
\text { Shona-S } \\
\text { Ndebele- } N \\
\text { Shangani-C }\end{array}$ & Part used & Preparation methods & $\begin{array}{l}\text { Target } \\
\text { parasites }\end{array}$ & $\begin{array}{l}\text { Availability } \\
\text { status }\end{array}$ & $\begin{array}{l}\text { Comments \& } \\
\text { precautions }\end{array}$ \\
\hline Acacia karroo Hayne. & \multirow[t]{2}{*}{ Fabaceae } & \multirow[t]{2}{*}{ Muzunga (S) } & \multirow[t]{2}{*}{ Root } & \multirow[t]{2}{*}{ Leave root in fowl run } & \multirow{2}{*}{$\begin{array}{l}\text { Fleas and } \\
\text { mites }\end{array}$} & \multirow[t]{2}{*}{ Always } & \multirow[t]{2}{*}{ Safe to use } \\
\hline Nyahangare E 11 & & & & & & & \\
\hline $\begin{array}{l}\text { Monadenium lugardiae } \\
\text { N.E. B. }\end{array}$ & \multirow[t]{2}{*}{ Euphorbiaceae } & \multirow[t]{2}{*}{ Chisvosve (S) } & \multirow[t]{2}{*}{$\begin{array}{l}\text { Whole } \\
\text { plant }\end{array}$} & \multirow[t]{2}{*}{ Crush and mix with water $24 \mathrm{~h}$} & \multirow[t]{2}{*}{$\begin{array}{l}\text { Ticks, } \\
\text { fleas }\end{array}$} & \multirow[t]{2}{*}{ Always } & \multirow[t]{2}{*}{$\begin{array}{l}\text { Handle with } \\
\text { care }\end{array}$} \\
\hline Nyahangare E 15 & & & & & & & \\
\hline $\begin{array}{l}\text { Albizia amara } \\
\text { (Roxb.)Boiv. }\end{array}$ & \multirow[t]{2}{*}{ Fabaceae } & \multirow[t]{2}{*}{ Umbola (N) } & \multirow[t]{2}{*}{ Leaves } & \multirow[t]{2}{*}{ Crush leaves + water + spray } & \multirow[t]{2}{*}{$\begin{array}{l}\text { Ticks, } \\
\text { fleas }\end{array}$} & \multirow[t]{2}{*}{ Seasonal } & \multirow[t]{2}{*}{ Effective } \\
\hline Nyahangare E 38 & & & & & & & \\
\hline Aloe excelsa A. Berger. & \multirow[t]{2}{*}{ Aloaceae } & \multirow{2}{*}{$\begin{array}{l}\text { Gavakava, } \\
\text { Mhangani(S) }\end{array}$} & \multirow{2}{*}{$\begin{array}{l}\text { Stemmy } \\
\text { leaves }\end{array}$} & \multirow{2}{*}{$\begin{array}{l}\text { Crush leaves, mix with water for } \\
24 \text { h \& spray }\end{array}$} & \multirow[t]{2}{*}{$\begin{array}{l}\text { Fleas, } \\
\text { ticks }\end{array}$} & \multirow[t]{2}{*}{ Seasonal } & \multirow[t]{2}{*}{ Safe to use } \\
\hline Nyahangare E 29 & & & & & & & \\
\hline $\begin{array}{l}\text { Aloe chabaudii } \\
\text { Schoenland. }\end{array}$ & \multirow[t]{2}{*}{ Aloaceae } & \multirow[t]{2}{*}{ Inhlaba (N) } & \multirow{2}{*}{$\begin{array}{l}\text { Succulent } \\
\text { leafy } \\
\text { stems }\end{array}$} & $\begin{array}{l}\text { Grind and soak and smear the } \\
\text { bird with sticky water }\end{array}$ & Lice & Always & Very effective \\
\hline Nyahangare E 37 & & & & & & & \\
\hline $\begin{array}{l}\text { Bauhinia petersiana } \\
\text { Bolle. }\end{array}$ & Fabaceae & Mutyatyambe (S) & Leaves & Crush leaves, mix with water & $\begin{array}{l}\text { Ticks, } \\
\text { Goats }\end{array}$ & Always & Safe to use \\
\hline Nyahangare E23 & & & & & & & \\
\hline Capsicum annuum L. & Solanaceae & Mhiripiri (S) & Fruits & Crush the fruits and mix with & Ticks & Always & Causes eye \\
\hline Nyahangare E 69 & & & & & & & \\
\hline $\begin{array}{l}\text { Carissa edulis (Forssk.) } \\
\text { Vahl. Nyahangare E39 }\end{array}$ & Apocynaceae & Umlugulu (N) & Leaves & $\begin{array}{l}\text { Grind leaves, mix with water in } \\
\text { the ratio } 1: 4 \text { and spray }\end{array}$ & $\begin{array}{l}\text { Lice and } \\
\text { ticks }\end{array}$ & Seasonal & $\begin{array}{l}\text { Wash hands } \\
\text { after use }\end{array}$ \\
\hline Cucumis anguria $L$. & Cucurbitaceae & Mujachacha (S) & Fruits & Collect ripe fruits (yellow), crush & Ticks & Seasonal & Have an \\
\hline Nyahangare E47 & & & & & & & $\begin{array}{l}\text { itching effect } \\
\text { on animals }\end{array}$ \\
\hline Ornithogalum sp & Asparagaceae & Chihanyanisi (S) & Roots & Crush and mix with water & Ticks & Always but & Very effective \\
\hline Nyahangare E59 & & & & & & & \\
\hline * & & Chimwamaruka (S) & $\begin{array}{l}\text { Leaves } \\
\text { and } \\
\text { branches }\end{array}$ & $\begin{array}{l}\text { Crush the leaves and branches } \\
\text { and mix with water }\end{array}$ & $\begin{array}{l}\text { Fleas and } \\
\text { ticks }\end{array}$ & $\begin{array}{l}\text { Always but } \\
\text { scarce }\end{array}$ & Very effective \\
\hline Cissus quadrangularis $L$. & Vitaceae & Chiololo (C), & Stems & Crush and mix with water to & Ticks & Always & Handle with \\
\hline Nyahangare E6 & & & & & & & $\begin{array}{l}\text { care, has an } \\
\text { itchy effect }\end{array}$ \\
\hline $\begin{array}{l}\text { Psydrax livida (Hiern) } \\
\text { Bridson }\end{array}$ & Rubiaceae & $\begin{array}{l}\text { Muvengahonye } \\
\text { (S) }\end{array}$ & Leaves & $\begin{array}{l}\text { Crush, mix with water and spray } \\
\text { or crush leaves and put on }\end{array}$ & $\begin{array}{l}\text { Ecto } \\
\text { parasites }\end{array}$ & Always & \\
\hline Nyahangare E20 & & $\begin{array}{l}\text { Umhlahlampethu } \\
\text { (N) }\end{array}$ & & & & & \\
\hline Rotheca eriophylla & Lamiaceae & Umnukanja (N) & Leaves & Macerate, soak with water and & Ticks, & Always & Very effective \\
\hline Nyahangare E35 & & & & & $\begin{array}{l}\text { Lice and } \\
\text { tsetse fly }\end{array}$ & & \\
\hline $\begin{array}{l}\text { Colophospermum } \\
\text { mopane (J. Kirk ex } \\
\text { Benth.) J. Kirk ex J. }\end{array}$ & Fabaceae & Mopani (S) & $\begin{array}{l}\text { Branches } \\
\text { and twigs }\end{array}$ & $\begin{array}{l}\text { Burn and apply ashes on animal } \\
\text { skin }\end{array}$ & $\begin{array}{l}\text { Ticks, } \\
\text { fleas, } \\
\text { mites }\end{array}$ & Always & Safe to use \\
\hline
\end{tabular}

(.) Kirk ex J.

Leonard.

Nyahangare E41

Combretum imberbe

Combretaceae

Muchenarota/ Mutsviri (S)

Nyahangare E55

Croton gratissimus Burch.

Euphorbiaceae Inkiza emhlope (N)
Leaves and twigs
Ash of the bark and twigs dusted on infestation sites

Use as bedding in the fowl run Lice

Nyahangare E48 
Table 5 Summary of plants used for ticks and other ecto parasites control, how they are used and status of availability (Continued)

\begin{tabular}{|c|c|c|c|c|c|c|c|}
\hline $\begin{array}{l}\text { Scientific name \& } \\
\text { Voucher number }\end{array}$ & Family name & $\begin{array}{l}\text { Local names } \\
\text { Shona-S } \\
\text { Ndebele-N } \\
\text { Shangani-C }\end{array}$ & Part used & Preparation method & $\begin{array}{l}\text { Target } \\
\text { parasites }\end{array}$ & $\begin{array}{l}\text { Availability } \\
\text { status }\end{array}$ & $\begin{array}{l}\text { Comments \& } \\
\text { precautions }\end{array}$ \\
\hline $\begin{array}{l}\text { Ptaeroxylon obliquum } \\
\text { (Thunb.) Radlk. } \\
\text { Nyahangare E27 }\end{array}$ & Rutaceae & $\begin{array}{l}\text { Umpahla, } \\
\text { Umpandula N, }\end{array}$ & Leaves & $\begin{array}{l}\text { Crush leaves, soak in water and } \\
\text { spray }\end{array}$ & $\begin{array}{l}\text { Ticks, } \\
\text { Fleas, } \\
\text { Lice }\end{array}$ & $\begin{array}{l}\text { Always but } \\
\text { scarce }\end{array}$ & Very effective \\
\hline $\begin{array}{l}\text { Euphorbia cooperi L. } \\
\text { Nyahangare E71 }\end{array}$ & Euphorbiaceae & Umhlonhlo (N) & Branches & $\begin{array}{l}\text { Smoke the walls of the fowl run } \\
\text { with the branches }\end{array}$ & Fleas & Always & $\begin{array}{l}\text { Handle with } \\
\text { care }\end{array}$ \\
\hline $\begin{array}{l}\text { Euphorbia ingens } \\
\text { E.Mey.ex Boiss. } \\
\text { Nyahangare E43 }\end{array}$ & Euphorbiacaea & $\begin{array}{l}\text { Mukondekonde } \\
\text { (S) }\end{array}$ & Stems & $\begin{array}{l}\text { Mix milk sap with water and } \\
\text { place on infested sites }\end{array}$ & $\begin{array}{l}\text { Fleas, } \\
\text { ticks }\end{array}$ & Always & $\begin{array}{l}\text { Avoid contact } \\
\text { with the eyes }\end{array}$ \\
\hline $\begin{array}{l}\text { Gnidia kraussiana } \\
\text { Meisn. } \\
\text { Nyahangare E70 }\end{array}$ & Thymelaeaceae & Chitupatupa (S) & $\begin{array}{l}\text { Whole } \\
\text { plant }\end{array}$ & $\begin{array}{l}\text { Crush and mix with water to } \\
\text { spray }\end{array}$ & Ticks & Always & Very effective \\
\hline $\begin{array}{l}\text { Lippia javanica } \\
\text { (Burm.f.) Spreng. } \\
\text { Nyahangare E46 }\end{array}$ & Verbenaceae & $\begin{array}{l}\text { Zumbani (S) } \\
\text { Umsuzwane (N) }\end{array}$ & $\begin{array}{l}\text { Leaves } \\
\text { and } \\
\text { branches }\end{array}$ & $\begin{array}{l}\text { Crush leaves mix with water } \\
\text { and spray, twigs can also be } \\
\text { used as bedding in fowl runs }\end{array}$ & $\begin{array}{l}\text { Ticks, } \\
\text { fleas, lice }\end{array}$ & Always & Safe to use \\
\hline $\begin{array}{l}\text { Maerua edulis } \\
\text { Gilg\&Gilg-Ben. DeWolf } \\
\text { Nyahangare E5 }\end{array}$ & Capparidaceae & Katunguru (S) & Roots & $\begin{array}{l}\text { mix M. edulis roots and } S \text {. } \\
\text { incanum fruits with water and } \\
\text { spray }\end{array}$ & Ticks & Always & Very effective \\
\hline $\begin{array}{l}\text { Ornithogalum sp } \\
\text { Nyahangare E59 }\end{array}$ & Alliaceae & Masimbe (S) & Bulb & $\begin{array}{l}\text { crush bulb, soak in water and } \\
\text { spray }\end{array}$ & Ticks & Always & Very effective \\
\hline $\begin{array}{l}\text { Datura stramonium L. } \\
\text { Nyahangare E51 }\end{array}$ & Solanaceae & $\begin{array}{l}\text { lyoyi (N), Chowa } \\
\text { (S) }\end{array}$ & Leaves & $\begin{array}{l}\text { Crush leaves mix with water } \\
\text { and spray on animal }\end{array}$ & $\begin{array}{l}\text { Ticks and } \\
\text { Lice }\end{array}$ & $\begin{array}{l}\text { Always but } \\
\text { scarce }\end{array}$ & Safe to use \\
\hline $\begin{array}{l}\text { Euclea divinorum Hiern. } \\
\text { Nyahangare E15 }\end{array}$ & Ebenaceae & Muchekesani(S) & Roots & $\begin{array}{l}\text { Crush leaves soak in water and } \\
\text { spray }\end{array}$ & $\begin{array}{l}\text { Fleas, } \\
\text { cattle }\end{array}$ & Always & \\
\hline * & & Mundorani (S) & Roots & $\begin{array}{l}\text { Crush dry roots and mix with } \\
\text { water }(50 \mathrm{~g} \text { in } 300 \mathrm{ml} \text { for } \\
3 \text { days })\end{array}$ & Ticks & $\begin{array}{l}\text { Always but } \\
\text { scarce }\end{array}$ & Very effective \\
\hline $\begin{array}{l}\text { Vernonia colorata } \\
\text { (Willd.) Drake. }\end{array}$ & $\begin{array}{l}\text { Compositae/ } \\
\text { Asteraceae }\end{array}$ & Munyatera (S) & Roots & $\begin{array}{l}\text { Crush mix with water for an } \\
\text { hour and spray }\end{array}$ & Ticks & $\begin{array}{l}\text { Always but } \\
\text { scarce }\end{array}$ & Very effective \\
\hline Nyahangare E16 & & & & & & & \\
\hline * & & Muvuwavuwa (S) & $\begin{array}{l}\text { Whole } \\
\text { plant }\end{array}$ & $\begin{array}{l}\text { Just put the plant in the fowl } \\
\text { run }\end{array}$ & $\begin{array}{l}\text { Fleas and } \\
\text { lice }\end{array}$ & $\begin{array}{l}\text { Always but } \\
\text { scarce }\end{array}$ & Very effective \\
\hline $\begin{array}{l}\text { Neorautanenia } \\
\text { brachypus }\end{array}$ & Fabaceae & Zhombwe (S) & Bulb & $\begin{array}{l}\text { Crush the bulb, mix with water } \\
\text { and spray }\end{array}$ & $\begin{array}{l}\text { Fleas, } \\
\text { ticks }\end{array}$ & Always & $\begin{array}{l}\text { Avoid water } \\
\text { contamination }\end{array}$ \\
\hline (Harms) C.A. Sm. & & & & & & & \\
\hline Nyahangare E65 & & & & & & & \\
\hline $\begin{array}{l}\text { Nicotiana tabacum L. } \\
\text { Nyahangare E68 }\end{array}$ & Solanaceae & Tobacco (E) & Water & Break and mix with water & Ticks & Always & Safe to use \\
\hline $\begin{array}{l}\text { Spirostachys africana } \\
\text { Sond. }\end{array}$ & Euphorbiaceae & Mutovhoti (S) & Barks & $\begin{array}{l}\text { Cut barks break and mix with } \\
\text { water }\end{array}$ & Ticks & Seasonal & Very effective \\
\hline Nyahangare E63 & & & & & & & \\
\hline Strychnos spinosa Lam. & Strychnaceae & Matamba (S) & $\begin{array}{l}\text { Unripe } \\
\text { fruits }\end{array}$ & $\begin{array}{l}\text { Crush unripe fruits, mix with } \\
\text { water and spray }\end{array}$ & Ticks & Always & Very effective \\
\hline
\end{tabular}


Table 5 Summary of plants used for ticks and other ecto parasites control, how they are used and status of availability (Continued)

\begin{tabular}{|c|c|c|c|c|c|c|c|}
\hline $\begin{array}{l}\text { Scientific name \& } \\
\text { Voucher number }\end{array}$ & Family name & $\begin{array}{l}\text { Local names } \\
\text { Shona-S } \\
\text { Ndebele-N } \\
\text { Shangani-C }\end{array}$ & Part used & Preparation method & $\begin{array}{l}\text { Target } \\
\text { pests }\end{array}$ & $\begin{array}{l}\text { Availability } \\
\text { status }\end{array}$ & $\begin{array}{l}\text { Comments \& } \\
\text { precautions }\end{array}$ \\
\hline \multicolumn{8}{|l|}{ Nyahangare E10 } \\
\hline $\begin{array}{l}\text { Tagetes minuta L. } \\
\text { Nyahangare E66 }\end{array}$ & $\begin{array}{l}\text { Compositae/ } \\
\text { Asteraceae }\end{array}$ & $\begin{array}{l}\text { Munyakambanje } \\
\text { (S) }\end{array}$ & $\begin{array}{l}\text { Whole } \\
\text { plant }\end{array}$ & Crush and mix with water & $\begin{array}{l}\text { Ticks, } \\
\text { fleas, } \\
\text { mites }\end{array}$ & Always & Safe to use \\
\hline $\begin{array}{l}\text { Terminalia sericea } \\
\text { Burch. ex DC. }\end{array}$ & Combretaceae & Mususu (S) & Leaves & Crush mix with water for spray & Ticks & Always & Very effective \\
\hline \multicolumn{8}{|l|}{ Nyahangare E36 } \\
\hline $\begin{array}{l}\text { Strychnos cocculoides } \\
\text { Baker. }\end{array}$ & Strychnaceae & Ubuhlali (N) & Fruit & $\begin{array}{l}\text { Squash the fruit and smear } \\
\text { contents on animal infested }\end{array}$ & Lice & Seasonal & Very effective \\
\hline \multicolumn{8}{|l|}{ Nyahangare E45 } \\
\hline $\begin{array}{l}\text { Vigna unguiculata L. } \\
\text { Nyahangare E67 }\end{array}$ & $\begin{array}{l}\text { Leguminosae - } \\
\text { Papilionoideae }\end{array}$ & Cowpea (E) & Pods & $\begin{array}{l}\text { Empty pods burnt and ash } \\
\text { applied on tick sites }\end{array}$ & Ticks & Always & Very effective \\
\hline $\begin{array}{l}\text { Xeroderris stuhlmannii } \\
\text { (Taub.)Mendonca } \\
\text { \&E.P.Sousa Nyahangare } \\
\text { E7 }\end{array}$ & Papilionaceae & Murumanyama (S) & Barks & $\begin{array}{l}\text { Crush stems and spread on } \\
\text { infestation sites }\end{array}$ & $\begin{array}{l}\text { Fleas, } \\
\text { ticks }\end{array}$ & Always & Very effective \\
\hline $\begin{array}{l}\text { Zantedeschia } \\
\text { albomaculata (Hook.) } \\
\text { Baill. }\end{array}$ & Araceae & $\begin{array}{l}\text { Mufanawembudzi } \\
\text { (S) }\end{array}$ & Stem & $\begin{array}{l}\text { Crush, mix with water and } \\
\text { drench }\end{array}$ & Ticks & Always & Very effective \\
\hline \multicolumn{8}{|l|}{ Nyahangare E62 } \\
\hline $\begin{array}{l}\text { Zanthoxylum capense } \\
\text { (Thunb.)Harv. } \\
\text { Nyahangare E22 }\end{array}$ & Rutaceae & Mukundanyoka (S) & Stems & $\begin{array}{l}\text { Crush stems and spread on } \\
\text { infestation sites }\end{array}$ & $\begin{array}{l}\text { Fleas, } \\
\text { ticks }\end{array}$ & Always & Safe to use \\
\hline $\begin{array}{l}\text { Xanthocercis } \\
\text { zambesiaca (Baker) } \\
\text { Dumaz-le-Grand Nya- } \\
\text { hangare E8 }\end{array}$ & Fabaceae & Muturufuwa (S) & Bark & $\begin{array}{l}\text { Crush the bark and soak in } \\
\text { water to form a soapy solution } \\
\text { for spraying }\end{array}$ & $\begin{array}{l}\text { Fleas and } \\
\text { ticks }\end{array}$ & Available & Safe to use \\
\hline $\begin{array}{l}\text { Pterocarpus angolensis } \\
\text { DC. Nyahangare E32 }\end{array}$ & Papilionoideae & $\begin{array}{l}\text { Umvagazi (N) } \\
\text { Mubvamaropa }\end{array}$ & $\begin{array}{l}\text { Barks, } \\
\text { branches }\end{array}$ & Mix with water & Ticks & Always & Safe to use \\
\hline $\begin{array}{l}\text { Sansevieria } \\
\text { hyacinthoides (L.) } \\
\text { Druce. Nyahangare E58 }\end{array}$ & Asparagaceae & $\begin{array}{l}\text { Chikwenga (S)/ } \\
\text { Bushfibre (E) } \\
\text { Mashamhanda (S) }\end{array}$ & $\begin{array}{l}\text { Stemmy } \\
\text { rhizomes }\end{array}$ & $\begin{array}{l}\text { Squash the stems, mix with } \\
\text { water and spray on ticks }\end{array}$ & Ticks & Always & $\begin{array}{l}\text { Handle with } \\
\text { care }\end{array}$ \\
\hline $\begin{array}{l}\text { Senna singueana (Del.) } \\
\text { Lock Nyahangare E13 }\end{array}$ & Fabaceae & $\begin{array}{l}\text { Mudyamhungu } \\
\text { Mukundanyoka (S) }\end{array}$ & Bark & Crush bark and mix with water & Ticks & Always & User friendly \\
\hline $\begin{array}{l}\text { Solanum incanum L. } \\
\text { Nyahangare E61 }\end{array}$ & Solanaceae & Nhundurwa (S) & Fruits & Crush fruits and mix with water & Ticks & Seasonal & $\begin{array}{l}\text { Handle with } \\
\text { care }\end{array}$ \\
\hline $\begin{array}{l}\text { Solanum panduriforme } \\
\text { E.Mey. Nyahangare E60 }\end{array}$ & Solanaceae & Nhundurwa (S) & Fruits & Crush fruits and mix with water & Ticks & Seasonal & $\begin{array}{l}\text { Handle with } \\
\text { care }\end{array}$ \\
\hline * & & $\begin{array}{l}\text { Chinyaride (S) } \\
\text { (fibre like) }\end{array}$ & $\begin{array}{l}\text { Roots and } \\
\text { the bulb }\end{array}$ & $\begin{array}{l}\text { Crush the roots/bulb and mix } \\
\text { with water }\end{array}$ & Ticks & $\begin{array}{l}\text { Always but } \\
\text { scarce }\end{array}$ & $\begin{array}{l}\text { Handle with } \\
\text { care }\end{array}$ \\
\hline $\begin{array}{l}\text { Kleinia sp Nyahangare } \\
\text { E50 }\end{array}$ & Asteraceae & Iphunja (N) & Leaves & $\begin{array}{l}\text { Crush leaves, mix with water } \\
\text { and rub on affected areas }\end{array}$ & Ticks & Scarce & Very effective \\
\hline $\begin{array}{l}\text { Ricinus communis L. } \\
\text { Nyahangare E42 }\end{array}$ & Euphorbiaceae & Umtshafuto (N) & Leaves & $\begin{array}{l}\text { Grind leaves and paste on tick } \\
\text { infested site }\end{array}$ & Ticks & Always & Very effective \\
\hline $\begin{array}{l}\text { Osyris lanceolata } \\
\text { Hochst. Nyahangare } \\
\text { E49 }\end{array}$ & Santalaceae & $\begin{array}{l}\text { Ingobamakhosi } \\
(\mathrm{N})\end{array}$ & Roots & $\begin{array}{l}\text { Pestle roots, soak in water and } \\
\text { spray }\end{array}$ & Ticks & $\begin{array}{l}\text { Always but } \\
\text { scarce }\end{array}$ & Very effective \\
\hline
\end{tabular}

* At the time of the survey, samples of these plants could not be found and require further follow up for positive identification. 
also found ticks to be the major problematic external parasite in cattle-rearing in South Africa and Zimbabwe respectively. There is a long history of the negative effects of ticks on productivity of cattle. Young [8] put the economic effects of ticks in SSA higher than tsetse flies. The effects of other parasites are not as high and debilitating as those of ticks which can cause several weakening and fatal conditions to the animals $[44,45]$. The high incidence of fleas and lice in poultry is not uncommon as these are the most common parasites affecting chickens. Maroyi [43] also reported a high presence of these pests in chickens in a survey in Nhema area of the Midlands province of Zimbabwe.

\section{Methods of controlling parasites}

There was a deliberate inclination to manage ecto-parasites in the highly ranked livestock species (cattle, indigenous chickens and goats) with commercial acaricides while there were few interventions in the other livestock species with some of them not receiving any attention at all. The preference of commercial acaricides can be explained by the fact that over a long period, commercial products have been demonstrated to be very effective and are thus the default pest control remedy. On the contrary, farmers perceive the efficacy of traditional practices to be on the low side even if those thoughts are not supported by hard scientific facts [46]. Government of Zimbabwe has also played a critical role in the promotion of commercial products over traditional practices through extension agencies as Government policy. In most developing countries, there is no formal policy on the use of pesticidal plants and traditional practices in general. It must also be noted that through the Department of Veterinary Services of Zimbabwe most acaricides are heavily subsidised for communal farmers [47]. This implies that, for as long as the services are available farmers will take this route for animal health care. It is when commercial acaricides are not available that farmers start using plants and other ethnoveterinary practices. Isman [13] noted that use of pesticidal plants is most prominent in the absence of commercial pesticides due to various reasons.

Challenges arise when governments no longer have capacity to meet this need and instances of this nature are occurring more frequently. Between the years 2000 and 2009 for example, Zimbabwe went through serious economic challenges and cattle herds would go for months without dipping because the government could not supply the required chemicals [48]. Prior to the economic challenges, community dipping infrastructure was also dilapidating due to neglect of the past three decades [49]. Availability of acaricides has improved slightly as a result of economic stability over the last couple of years. Failure of governments to meet the needs of farmers is not a Zimbabwean problem alone but a feature in other countries as well; for example in some South African communities [50].
The pronounced use of acaricidal plants in combination with commercial acaricides observed in the survey shows the complementarity of the two practices in holistically dealing with ectoparasites. Other researchers have reported this trend in several ethnoveterinary studies $[42,46,51]$.

It is not surprising that the major reason for inconsistent dipping was associated with lack of Government support. As alluded to before, farmers had become used to Government providing the acaricides and ensuring that animal health is well-catered for through the Department of Veterinary Services but this has since changed as the economic climate is changing and Government ministries are always under-funded. As farmers try and adapt to the new set-up, it is inevitable that they feel the acaricides are over-priced and that the Government is not fully supporting them. The issue of inadequate water supply as another challenge is likely to increase as more frequent droughts and erratic rainfall patterns are anticipated due to the effects of climate change. The design of the plunge dip tanks in the country is such that they must be filled with water (about 20000 litres) so that many cattle can be immersed when they dip in. In the absence of sufficient quantities of water, it will be impossible to dip the cattle.

\section{Use of acaricidal plants for control of parasites}

The high proportion of respondents $(72.1 \%)$ with knowledge of plants with pesticidal properties is perhaps indicative of a very good link between primary animal health care and traditional practices. A $100 \%$ affirmation to knowledge of pesticidal plants was anticipated but it became apparent during the survey that some respondents had confused pesticidal plants with medicinal plants. Nonetheless, the knowledge can be explained by that many people $(>80 \%)$ in the world rely on traditional practices to address human health problems [52]. Plants are a critical component of traditional medicines and pesticides [53]. Most of traditional knowledge is not as yet comprehensively documented and is passed on orally from generation to generation which could be the reason why parents and grandparents are the biggest source of this knowledge in this study. In a study on ethnoveterinary medicines [51], $61.5 \%$ of the sampled population also reported getting knowledge from parents and grandparents. The various media platforms were cited as the least significant source of information but it must be noted that it can be the most powerful tool in the promotion and development of traditionally based remedies especially if the younger generation are to be involved.

Some of the plants that were reported were well-known while others were known by a few people. In Table 5, there is a possibility of inter-use of the plants identified. Some are stated as useful in controlling fleas, lice, flies etc. with no specific mention of ticks but it is possible that the pesticidal properties can also work against ticks. Future studies 
should investigate this possibility. The most common plants across the districts were C. quadrangularis, L. javanica, $P$. livida and Aloe sp. It is important to note that it does not necessarily mean that the most mentioned plants are the most effective as only efficacy experiments can determine that. Some plant species have over time, been well-known to work in different places of the world thus exposing them to many people. The most popular plants can help researchers prioritise plants for further investigations to meet farmer needs. Knowledge of traditional products is a trade which some people depend on for livelihood and it is very likely that such people are reluctant to divulge and share the information. This could explain why some plants could be less popular. Some of the species in the list have since been confirmed through experimentation to be acaricidal for example, L. javanica [22], S. spinosa and S. incanum [23]. Aloe ferox was reported as a tick control remedy in some South African villages [42]. Aloe chabaudii, N. mitis are also some examples of plants reported in another survey in Nhema village in Zimbabwe to be acaricidal [43].

Other plant species reported in this survey, however, do not have known acaricidal or pesticidal properties yet but have other uses in ethnoveterinary medicine. Aloe sp are effective anti-microbials and mostly used in the treatment of poultry diseases and other internal parasites $[51,54,55]$. The recorded uses of $C$. quadrangularis are of a medicinal nature than pesticidal [56]. However respondents highly regarded this plant and in Chiredzi it was called "Chiololo" in Shangani which can be literally translated to "highly effective" in English. Psydrax livida belongs to a very important group of plants locally known in Shona as "Muvengahonye" (hater of maggots) with many uses in ethnoveterinary medicine in tropical Africa but mainly famed for their antiseptic properties and treatment of wounds $[43,57,58]$. Other plants in the group include Canthium huillense and Clausena anisata. There have not been reports of these plants against ticks elsewhere but some farmers indicated that the leaves are excellent insect and tick repellents.

\section{Other issues}

The use of water and leaves is almost a standard practice in most traditional remedies. Leaves are ideal because they ensure sustainability of the plant and water is a cheap universal solvent. In further studies, there may be need to use organic solvents to fully optimise the extraction process because water has its polarity limitations $[59,60]$. In all the districts, through the focus group discussions, most farmers were not comfortable sharing their ethno-knowledge for fear of exploitation but later relaxed their stance after much persuasion and assurance that the research was not for commercial gain. Trust is therefore a critical factor in accessing detailed and accurate information. This just shows some of the challenges that need to be addressed to fully develop ethnoveterinary science in pest control.

\section{Conclusions and recommendations}

The study showed that there is still a considerably strong use and wide knowledge of plant-based materials in controlling cattle ticks and other livestock parasites in drier parts of the country. A total of 51 plant species were identified that can be used to control ticks in semi-arid areas of Zimbabwe but the most popular across the four districts were C. quadrangularis, Aloe sp and Psydrax livida. The foliage of these plants is reportedly crushed and mixed with water after which the extracts are sprayed on animals. There is need, however, to go a step further and conduct safety, efficacy and optimisation trials to verify farmers' claims that the plants are safe and effective for promotion of adoption. It is also of paramount importance to start engaging the Government of Zimbabwe to explore ways of creating an enabling environment for the formal recognition, development and use of acaricidal plants and other ethnoveterinary practices in the primary health care of livestock. This should be a critical step in the development of a robust alternative or integrated system for managing cattle ticks, especially where veterinary services are limited. Intellectual property rights are an area of concern that needs to be investigated and addressed. Since the current type of work is still not yet fully developed locally, there may be need to examine what models other countries strong in the use of indigenous knowledge systems are using and assess if such models can also be adapted locally.

\section{Competing interests}

The authors declare that there are no competing interests in this research.

\section{Authors' contributions}

ETN: This work is part of my PhD thesis. I did the ethnoverterinary plant survey in the semi-arid areas of the country. BMM is my supervisor and assisted in the development of the conceptual framework, the survey tools, development and reviewing of this manuscript. TM assisted in the development of the paper, data entry and analysis and proof reading of the manuscript. All the authors read and approved the final submitted manuscript.

\section{Acknowledgements}

The authors acknowledge financial support received from the International Foundation for Science (IFS AB22825) and the European Commission's European Development Fund ACP S\&T Programme grant FED /2013/329272 (OPTIONs). We thank the communities in Muzarabani, Sanyati (Kadoma), Chiredzi and Matopos for the sharing their experiences and information on the use of local plants to control livestock ecto-parasites. Authors are grateful for the technical and logistical support provided by the Department of Agricultural Technical and Extension Services and Division of Veterinary Services officers in the four districts. The expertise provided in the correct identification of plant species from the staff at the Zimbabwe National Herbarium and Botanic Garden is greatly appreciated. The authors would like to express their gratitude to all the anonymous reviewers for their invaluable comments on the drafts of this paper.

\section{Author details}

${ }^{1}$ Department of Animal Science, Faculty of Agriculture, University of Zimbabwe, P O Box MP167, Mt Pleasant, Harare, Zimbabwe. ${ }^{2}$ Department of Soil Science and Agricultural Engineering, Faculty of Agriculture, University of Zimbabwe, P O Box MP 167 Mt Pleasant, Harare, Zimbabwe. 
Received: 18 July 2014 Accepted: 29 January 2015

\section{Published online: 30 April 2015}

\section{References}

1. LID. Livestock in poverty focused development. Crewkerne, UK: Livestock in Development (LID); 1999.

2. Stafford III KC. Tick Management Handbook. An integrated guide for homeowners, pest control operators and public health officials for the prevention of tick-associated diseases. New Haven, USA: The Connecticut Agricultural Experiment Station; 2004.

3. Ghosh S, Azhahianambi P, Yadav MP. Upcoming and future strategies of tick control. A review. J Vector Dis. 2007;44(2):79-89.

4. Schroeder B, Reilly BK. A comparison between tick species collected in a controlled and control free area on a game ranch in South Africa. J S Afr Vet. 2013;84:1. http://www.scielo.org.za/ scielo.php?script=sci_arttext\&pid=S101991282013000100009\&lng=en\&nrm=iso.

5. Jongejan F, Uilenberg G. The global importance of ticks. Parasitology. 2004;129, (Suppl S3 - 14) DOI: 10.1017/S0031182004005967

6. Minjauw B, Mcleod A. Tick -borne diseases and poverty. The impact of ticks and tick-borne diseases on the livelihoods of small-scale and marginal livestock owners in India and eastern and southern Africa, Research Report, DFID - AHP, Centre for Tropical Veterinary Medicine (CTVM). UK: University of Edinburg; 2003. p. Pp16.

7. Perry B, Randolph T, Omore A, Perera O, Vatta A. Improving the health of livestock kept by the resource-poor in developing countries. In: Owen $E_{\text {, }}$ Jayasuriya KA, Smith T, editors. Livestock and Wealth Creation: Improving the husbandry of animals kept by resource-poor people in developing countries. UK: Nottingham University Press; 2005. p. 233-62.

8. Young AS, Groocock CM, Kariuki DP. Integrated control of ticks and tick-borne diseases by cattle in Africa. Parasitology. 1988;96:403-32.

9. Scialabba N. Factors influencing organic agriculture policies with a focus on developing countries. Basel, Switzerland: IFOAM 2000 Scientific Conference; 2000. http://www.fao.org/docs/eims/upload/230159/BaselSum-final.pdf.

10. Graf JF, Gogolewski R, Leach-Bing N, Sabatini GA, Molento MB, Bordin EL, et al. Tick control: an industry point of view. Parasitology. 2004:129:5427-42.

11. Godfray HCJ, Beddington JR, Crute IR, Haddard L, Muir JF, Preety J, et al. Food security: the challenge of feeding 9 billion people. Science. 2010;327:812-8.

12. Mwine J, Van Damme P, Kamoga G, Kudamba, Nasuuna M, Jumba F. Ethnobotanical survey of pesticidal plants used in South Uganda: case study of Masaka district. J Med Plants Res. 2010;5(7):1155-63.

13. Isman MB. Perspective Botanical Insecticides: for richer for poorer. Pest Manag Sci. 2008;64:8-11.

14. Benavides E, Hernández G, Romero N, Castro A, Rodrígues B. Preliminary evaluation of Neem (Azadirachta indica) extracts as an alternative for cattle tick, Boophilus microplus control. Rev Colomb Entomol. 2001;27(1-2):1-8.

15. Webb EC, David M. The efficacy of neem seed extract (Azadirachta indica) to control tick infestation in Tswana, Simmentaler and Brahman cattle. S Afr J Anim Sci. 2002;32(1):1-6.

16. Kaposhi CKM. The role of natural products in integrated tick management in Africa. Insect Sci Appl. 1992;13(4):595-8.

17. Gadzirayi CT, Mutandwa E, Mwale M, Chindundu T. Utilization of Tephrosia vogelii in controlling ticks in dairy cows by small-scale commercial farmers in Zimbabwe. Afr J Biotechnol. 2009;8:4134-6.

18. Khudrathulla M, Jagannath MS. Effect of methanol extract of Stylosanthes scabra on ixodidae ticks of animals. Indian J Anim Sci. 2000;70(10):1057-8.

19. Van Puyvelde L, Geysen D, Ayonbangira FX, Hakizamungu E, Nshimiyimana A, Kalisa A. Screening of medicinal plants of Rwanda for acaricidal activity. J Ethnopharmacol. 1985:13:209-15.

20. Malonza MM, Dipeolu OO, Amoo AO, Hassan SM. Laboratory and field observations on anti-tick properties of the plant Gynandropsis gynandra (L.) Brig. Vet Parasitol. 1992;42:123-36.

21. de Barros ATM, Evans DE. Effects of some pasture grasses on infestive larvae of the cattle tick Boophilus microplus. Pesquisa Vet Brasil. 1989;9(1-2):17-21.

22. Madzimure J, Nyahangare ET, Hamudikuwanda H, Hove T, Stevenson PC, Belmain SR, et al. Acaricidal efficacy against cattle ticks and acute oral toxicity of Lippia javanica (Burm.F) Spreng. Trop Anim Health Pro. 2011:43:481-9.
23. Madzimure J, Nyahangare ET, Hamudikuwanda H, Hove T, Stevenson PC, Belmain SR, et al. Efficacy of Strychnos spinosa (Lam.) and Solanum incanum L. aqueous fruit extracts against cattle ticks. Trop Anim Health Pro. 2013:45:1341-7.

24. Stevenson P, Simmonds M, Belmain S. Caesalpinioid woodlands of Southern Africa: optimising the use of pesticidal plants. Chatham: Southern African Pesticidal Plants (SAPP) Project. Final Technical Report. Natural Resources Institute, University of Greenwich; 2010.

25. Anonymous. Animal health [Cattle cleansing] amendment regulations, statutory instrument 78 of 1997, Supplement to the Zimbabwean Government dated to the $28^{\text {th }}$ of March 1997. Harare: Government Printer; 1997.

26. UNDP, PRF, IDS. Human development report Zimbabwe. Zimbabwe: United Nations Development Programme, Poverty Reduction Forum, Institute of Development studies; 1998.

27. Pedersen C, Madsen J. Constraints and opportunities for improved milk production and calf rearing in Sanyati communal area, Zimbabwe. Livest Res Rural Dev. 1998, 10 (1) Retrieved February 11, 2015, from http:// www.Irrd.cipav.org.co/lrrd10/1/pede101.htm

28. Mugandani R, Wuta M, Makarau A, Chipindu B. Re-classification of agroecological regions of Zimbabwe in conformity with climate variability and change. ACSJ. 2012;20(s2):361-36.

29. Njorogea GN, Bussmann RW. Herbal usage and informant consensus in ethnoveterinary management of cattle diseases among the Kikuyus (Central Kenya). J Ethnopharmacol. 2006;108(3):332-9.

30. Quave CL, Pieroni A, Bennett BC. Dermatological remedies in the traditional pharmacopoeia of Vulture-Alto Bradano, inland southern Italy. J Ethnobiol Ethnomed. 2008:4:5. doi: 10.1186/1746-4269-4-5.

31. Confessor MVA, Mendonça LET, Mourão JS, Alves RRN. Animals to heal animals: ethnoveterinary practices in semiarid region. Northeastern Brazil J Ethnobiol Ethnomed. 2009;5:37. Doi: 10.1186/1746-4269-5-37.

32. Muchadeyi FC, Sibanda S, Kusina NT, Kusina J, Makuza S. The village chicken production system in Rushinga District of Zimbabwe. Livest Res Rural Dev. 2004; 16 (6) from http://www.lrrd.org//rrd16/6/much16040.htm

33. Mutibvu T, Maburutse BE, Mbiriri DT, Kashangura MT: Constraints and opportunities for increased livestock production in communal areas: A case study of Simbe, Zimbabwe. Livest Res Rural Dev 2012, 24, (165) Retrieved February 12, 2015, from http://www.lrrd.org/lrrd24/9/muti2 4165.htm

34. Muchadeyi FC. Assessment of genetic diversity of Zimbabwe Village chicken eco-types, PhD thesis. Gottingen Germany: Cuvillier Verlag; 2007.

35. Dovie DBK, Shackleton CM, Witkowski ETF. Valuation of communal area livestock benefits, rural livelihoods and related policy issues. Land Use Policy. 2006;23(3):260-71.

36. Mavedzenge BZ, Mahenehene J, Murimbarimba F, Scoones I, Wolmer W. Changes in the Livestock Sector in Zimbabwe Following Land Reform: The Case of Masvingo Province. A Report of a Discussion Workshop. IDS. 2006, Brighton. Retrieved May 14, 2012, from http://www.ids.ac.uk/files/ Masvingo_workshop_report.pdf

37. Ndebele JJ, Muchenje V, Mapiye C, Chimonyo M, Musemwa L, Ndlovu T. Cattle breeding management practices in the Gwayi smallholder farming area of South-Western Zimbabwe. Livest Res Rural Dev. 2007;19 (12) Retrieved February 11, 2015, from http://www.lrrd.org//rrd19/12/ ndeb19183.htm

38. Svotwa E, Hamudikuwanda H, Makarau A. Influence of climate and weather on cattle production in semi-arid communal areas of Zimbabwe, Electron. J Environ Agric Food Chem. 2007;6:1838-50.

39. Ndlovu RL, Bwakura T, Topps JH. Donkeys, people and development. In: Starkey P, Fielding D, editors. A resource book of the animal traction network for eastern and Southern Africa (ATNESA). Wageningen, the Netherlands: ACP-EU Technical Centre for Agricultural and Rural Cooperation (CTA); 2004. p. 244

40. Mlambo T, Mbiriri DT, Mutibvu T, Kashangura MT. Village chicken production systems in Zhombe communal area of Zimbabwe. Livest Res Rural Dev. 2011;23:154.

41. Mogotsi K, Nyangitob MM, Nyariki DM. The role of drought among agro-pastoral communities in a semi-arid environment: the case of Botswana. J Arid Environ. 2013;91:38-44.

42. Moyo B, Masika PJ. Tick control methods used by resource-limited farmers and the effect of ticks on cattle in rural areas of the Eastern Cape Province. South Africa Tropl Anim Health Pro. 2009;41(4):517-23. 
43. Maroyi A. Use of traditional veterinary medicine in Nhema communal area of the Midlands province. Zimbabwe Afri J Tradit Complem. 2012;9(3):315-22.

44. Peter RJ, Van den Bossche P, Penzhorn BL, Sharp B. Tick, fly, and mosquito control-lessons from the past, solutions for future. Vet Parasitol. 2005;132:205-15. doi: 10.1016/j.vetpar.2005.07.004.

45. Muchenje V, Dzama K, Chimonyo M, Raats JG, Strydom PE. Tick susceptibility and its effects on growth performance and carcass characteristics of Nguni, Bonsmara and Angus steers raised on natural pasture. Animal. 2008;2(2):298-304

46. Gumbochuma G, Hamandishe VR, Nyahangare ET, Imbayarwo-Chikosi VE Ncube S. Ethnoveterinary practices for poultry and cattle in Zimbabwe: a case study of Takavarasha village. SJAS. 2013;2(12):355-9.

47. Chamboko T, Mukhebi AW, Callaghan CJO, Petera TF, Kruskab RL, Medley GF, et al. The control of heartwater on large-scale commercial and smallholder farms in Zimbabwe. Prev Vet Med. 1999;39(3):191-210.

48. Gunjal K, Goodbody S, Delbaere J, Kenefick E, Rammala V. FAO/WFP crop and food security assessment mission to Zimbabwe, Food and Agriculture Organisation of the United Nations, Rome. Rome: World Food Programme; 2009 .

49. Chatikobo P, Kusina NT, Hamudikuwanda $H$, Nyoni O. A monitoring study of the prevalence of dermatophilosis and parafilariosis in cattle in a smallholder semi-arid farming area in Zimbabwe. Trop Anim Health Pro. 2004;36:207-15.

50. Hlatshwayo M, Mbata PA. Survey of tick control methods used by resource-poor farmers in the Qwa-Qwa area of the eastern Free State Province, South Africa. Onderstepoort J Vet. 2005;72:245-9.

51. Masimba ES, Mbiriri DT, Kashangura MT, Mutibvu T. Indigenous practices for the control and treatment of ailments in Zimbabwe's village poultry. Livest Res Rural Dev. 2011:23:257.

52. Jabbar A, Akhtar MS, Muhammed G, Lateef M. Possible role of ethnoveterinary medicine in poverty reduction in Pakistan: use of botanical Anthelmintics as an example. JASS. 2005;1(2):187-95.

53. Sindhu ZUD, Igbar Z, Khan MN, Jonsson NN, Siddique M. Documentation of ethno-vetrinary practices used for treatment of different ailments in a selected hilly area of Pakistan. 201x Int J Agr Biol. 2010;12:353-8.

54. Mwale M, Bhebhe E, Chimonyo M, Halimani TE. Use of herbal plants in poultry health management in the Mushagashe small-scale commercial farming area in Zimbabwe. Int J App Res Vet M. 2005:3(2):163-70.

55. Moreki JC. Use of ethnoveterinary medicine in family poultry health management in Botswana: a Review. J Vet Adv. 2012;2(6):254-60.

56. Murthy EN. Ethno medicinal plants used by gonds of Adilabad district, Andhra Pradesh, India. Int J Pharm \& Life Sci. 2012;3(10):2034-43.

57. Mapara J. Indigenous knowledge systems in Zimbabwe: juxtaposing postcolonial theory. JPAS. 2009;13(1):139-55.

58. Mukandiwa L, Naidoo V, Eloff JN. In vitro antibacterial activity of seven plants used traditionally to treat wound myiasis in animals in Southern Africa. JMPR. 2012;6(27):4379-88.

59. Belmain SR, Amoah BA, Nyirenda SP, Kamanula JF, Stevenson PC. Highly variable insect control efficacy of Tephrosia vogelii chemotypes. J Agric Food Chem. 2012;60:1055-66.

60. Grzywacz D, Stevenson PC, Mushobozi WL, Belmain S, Wilson K. The use of Indigenous ecological resources for pest control in Africa. Food Sec. 2013. doi 10. 1007/ S12571-013-0313-5

\section{Submit your next manuscript to BioMed Central and take full advantage of:}

- Convenient online submission

- Thorough peer review

- No space constraints or color figure charges

- Immediate publication on acceptance

- Inclusion in PubMed, CAS, Scopus and Google Scholar

- Research which is freely available for redistribution

Submit your manuscript at www.biomedcentral.com/submit 